Therefore, the rate at $8 \mathrm{I}^{\prime} 5=-\mathbf{I} . S \mathrm{~S}+(-0.00509 \times \mathbf{I} 48.84$ $=-2 \cdot 64$.

Observed mate in $8 r^{\circ} 5=-1 \cdot 55$. Computed rate in 81.5 $=-2.64$. The losing rate at $\mathrm{T}$ must therefore be diminished by $I^{\circ} \circ 9$, making the newly found $R=-0^{\circ} 79$ instead of $-I \cdot S 8$. For any chronometer which has been allowed to remain at the Observatory for a period of five weeks the certificate of test issued with the instrument contains the necessary data for calcu. lating the correction due to imperfect thermal adjustment.

\section{THE WHITWORTH SCHOLARSHIPS}

THE following Memorandum on the Whitworth Scholarships, prepared by Sir Joseph Whitworth, has been approved by the Lords of the Committee of Council on Education, South Kensington :-

I. The experience of the past competitions for my scholarships has proved to me the necessity of establishingerules which shall insure that the holders of scholarships shall devote themselves to the studies and practice necessary for mechanical engineering during the tenure of the scholarships.

2. To effect this I propose to the Lords of the Committce of Council on Education that as soon as possible, i.e. in the competition of 1875 , every candidate for a scholarship should produce a certificate that he has worked in a mechanical engineer's shop, or in the drawing office of a mechanical engineer's shop, for two years consecutively. In 1874 six months' consecutive work only in the enginecrs shop will be required. The candidate must be under 22 years of arre.

3. The candidate for the scholarship will be examined in the appointed sciences; in smith's work, turning, filing, and fitting, pattern making and moulding, as already established, and the same marks will be awarded as at present.

4. In 1875 and the following years each holder of a scholarship appointed under these new rules will be required to produce satisfactory evidence at the termination of cvery year that he has made proper advances in the sciences and practice of mechanical engineering by coming up for an examination similar to that which is prescribed for the competition both in theory and practice.

5. The scholarships may be held for three years, but may be withdrawn at the end of each year if the scholar has not made satisfactory progress.

6. The number of scholarships in the competition of 1874 will be reduced from ten to six. Each scholarship will be of a fixed annual value of $100 \%$, together with an additional annual sum determined by the results of the progress made in the preceding year.

7. At the end of each year's tenure of the scholarship, the scholars appointed under these new rules will, as before stated, be examined in theory and in practice in the same manner as in the competition for the scholarships. On the results of this cxamination the following payments, in addition to the $100 l$. before mentioned, will be made among each year's set or batch of scholars:-To the scholar who does best in the examination, $100 \%$; to the second, $60 l$. ; to the third, $50 l$.; to the fourth, $40 l$. ; to the fifth, $30 l$. ; and to the sixth, $20 l$. ; provided that each scholar has made such a progress as is satisfactory to the Department of Science and Art, which will determine if the sum named, or any other sum, shall be awarded.

8. At the expiration of the three years' tenure of the scholarships under these new regulations a further sum of $300 l$. will be awarded in sums of $200 \%$. and $100 \%$. to the two scholars of each year's set or batch who have done best during their tenure of scholarship.

In this way it will be possible for the best of the scholars at the end of his period of tenure of the scholarship to have obtained $800 l$, and the others in proportion.

9. The prizes under paragraph 7 will be awarded according to the total number of marks obtained by the students in practice and theory in the examination at the end of the year. The prizes under paragraph 8 will be awarded by adding together the marks obtained by the students at the end of each of the three years.

\section{SCIENTIFIC SERIALS}

THE current number of the Zoologist commences with a notice by the editor, of MIr. Lloyd's "Official Handbook to the Crystal Palace Aquarium." In an interesting historical sketch of the growth of aquaria, he divides its development during the last forty years into three eras, the earliest bcing the in. structive, the second the poetic and fashionable, and the present the commercial. The early development of the aquarium is then entered into, the rork done by Bowerbank. Dau. beny, and Warington being! fully described. This is followed by a review of Mr. T. J. Moggridge's work on IIarvestidea that these insects do accumulate secds in store-houses for winter consumption is correct, contrary to the assertions of Kirby, Latreille, and other high authorities. What is very pecu. liar is that these seeds scarcely ever show any tendency to gering Ants and Trapdoor Spiders, in which the author, from a careful and painstaking series of excellent observations on the habits of ants, which are described in detail, shows that the old minate, though under apparently very favourable circumstances. -Mr. Cornish notes the occurrence of the following fish at Penzance :-The Black Fish (Centrolophus pompilus), the Solenette (Monochirus linguatuhus), the Braize (Pagrus vulgaris), Bluch's Gurnard (Trigla blochii), and the Torpedo (Raia torpedo). -MIr. F. H. Balkwill, in reply to a critical note which appeared in this journal (NATURE, July 24, p: 252) on a paper by him in the Zoologist for July last, objects to his remarks being thrown into the general form; the fact that the forms and arrangements of teeth in vertebrates is practically infinite, bcing assumed by him. But that such is very far from being the case will be agreed to by all zoologists; the types and arrangements of tceth being extremely few in comparison to what they might be. The argument does not require, as Mr. Balkwill thinks, the proof of the statement that the teeth of the wombat, dog, \&c., should be of low type and simple development, which they are not and he may be assured that all "genuine Darwinists" are of opinion that when two not distant types of animal life are in a position to occupy new and separate regions, the fact that their food can only be obtained from two sources, namely, animal and vegetable tissues, invariably leads to their divergence in two directions only, that is, towards a carnivorous and a herbivorous conformation. Therefore the non-placental type, on occupying Australasia, as well as the placentalia in the rest of the world, have differentiated into flesh-eaters and vegetable-eaters, each having developed, by natural selection, organs suitable for procuring their accustomed diet. It is not therefore to be wondered at that these organs should present many points of similarity in the two main divisions of the Mammalia.

Baron von MIALTZan gives in the second number of the $Z$ eitschrift fïr Ethnologie for 1873 , an account of his travels in Arabla, and points out the various causes which have opposed the advance of our knowledge of its interior. Amongst these religion has acted as the most powerful obstacle, the exclusive. ness of the Islam faith having, in fact, so effectually closed the country to modern research, that there are still many spots of which nothing is known beyond what Ptolemy was able to tell us. Baron von Mraltzan selected the most southern extremity of the peninsula, which is as yet a tabula rasa on our maps, for the scene of his explorations. $\mathrm{He}$ drans attention to the artistic skill exhibited by these people in statuary and carving, before they fell under the rule of their Mahomedan conquerors from Central Arabia, when all their earlier civilisation was rudely checked and their language super. seded, while they were then also first driven to adopt a monadic mode of life. In spite, however, of amalgamation with central Arabian elements, the population of South Arabia still admits of division into two distinct peoples, the Sabäer and the Ilimyarites, the former of whom have light yellow skins, while the latter, whose name he derives from Hamr, red, are so dark-skinned as to be genrally classed amongst the black races. Baron MIaltzan observed a curious physical character in the family of the Himyarite rulers of the Fodli, or Ozmani-State, many of whom, both males and females, had six fingers and six toes on both hands and feet. This peculiarity is looked upon by the people at large as a special mark of blue blood, and prized accordingly by the possessors. It would seem that the practice of forming consan. guineous marriages, which prevails in the Fodli, as in other ruling houses, may of itself explain, as a mere case of hereditary recurrence, the appearance of this physiological character in nu. merous and remote members of the family. The author concludes his paper with an appenl to men of Science to turn their attention to a region which is at once so little known and so rich in materials of interest for physiologists, ethnologists, and geographers.Herr von Martens, in a critique on Prof. Strobel's paper on the appearance of Unio shells in the pilc-dwellings of Upper Italy 